\title{
Playing to continue being a child and freeing itself from the confinement of the hospitalization under precaution
}

\author{
Brincando para continuar a ser criança e libertar-se do confinamento da hospitalização em precaução
} Jugando para continuar siendo niño y libertarse del confinamiento de la hospitalización bajo precaución

\author{
Jéssica Renata Bastos Depianti ${ }^{1,2}$ (iC) \\ Luciana de Lione Melo ${ }^{3}$ \\ Circéa Amália Ribeiro ${ }^{1}$
}

1. Universidade Federal de São Paulo. São Paulo, SP, Brasil. 2. Universidade Federal do Espírito Santo. Vitória, ES, Brasil.

3. Universidade Estadual de Campinas. Campinas, SP, Brasil.
Corresponding author:

Jéssica Renata Bastos Depianti.

E-mail: jrbdepianti@gmail.com

Submitted on 10/15/2017.

Accepted on $03 / 14 / 2018$.

DOI: 10.1590/2177-9465-EAN-2017-0313

\begin{abstract}
Objective: To understand the meaning of playing for the hospitalized child under precaution. Method: Qualitative research where Symbolic Interactionism is the theoretical framework and Qualitative Content Analysis is the methodological one. It was attended by eight children aged between 5 and 10. Data were collected through participant observation of playful activities developed with the child by a nurse-researcher and semi-structured interviews mediated by story-drawing with theme. Results: Data showed the evolution of the interactions among toy, researcher and child; their rapid acceptance to get involved in playing; the way they explore the toys; the desire to free themselves from confinement; the relief of stress, the mastery of the situation and the protagonism enabled by the playing; the way they outline the hospital and the importance of having someone to play. Final considerations: Nurses should use creativity, seeking strategies that allow the child to play in this environment full of restrictions.
\end{abstract}

Keywords: Play and Playthings; Hospitalized Child; Patient Isolation; Pediatric Nursing.

\section{Resumo}

Objetivo: Compreender o significado do brincar para a criança hospitalizada em precaução. Método: Pesquisa qualitativa, sendo o Interacionismo Simbólico o referencial teórico e a Análise Qualitativa de Conteúdo, o metodológico. Participaram oito crianças, com idade entre 5 e 10 anos. Os dados foram coletados por observação participante de atividades lúdicas desenvolvidas com a criança por uma enfermeira pesquisadora e entrevista semiestruturada mediada pelo desenho-estória com tema. Resultados: Os dados revelaram a evolução das interações entre brinquedo, pesquisadora e criança; sua pronta aceitação para envolver-se na brincadeira; a maneira como ela explora os brinquedos; o desejo de libertar-se do confinamento, o alívio do estresse, o domínio da situação e o protagonismo propiciados pelo brincar; a maneira como ela significa o hospital e a importância dela ter alguém para brincar. Considerações finais: É preciso que o enfermeiro use sua criatividade, buscando estratégias que permitam à criança brincar nesse ambiente repleto de restrições.

Palavras-chave: Jogos e Brinquedos; Criança Hospitalizada; Isolamento de Pacientes; Enfermagem Pediátrica.

\section{Resumen}

Objetivo: Comprender el significado del jugar para el niño hospitalizado bajo precaución. Método: Investigación cualitativa, siendo el Interaccionismo Simbólico el marco teórico y el Análisis Cualitativo de Contenido, el metodológico. Participaron ocho niños de entre 5 y 10 años. Datos recolectados mediante observación participante de actividades lúdicas desarrolladas con el niño por una enfermera investigadora y entrevista semiestructurada mediada por dibujo-historia con tema. Resultados: Los datos mostraron la evolución de las interacciones entre juguete, investigadora y niño; su pronta aceptación para involucrarse en el juego; la forma cómo utiliza los juguetes; el deseo de liberarse del confinamiento; el alivio del estrés, el dominio de la situación y el protagonismo propiciados por el jugar; la forma en que representa el hospital y la importancia de tener alguien con quien jugar. Consideraciones finales: El enfermero debe utilizar su creatividad, buscando estrategias que permitan al niño jugar en ese ambiente lleno de restricciones.

Palabras clave: Juego e Implementos de Juego; Niño Hospitalizado; Aislamiento de Pacientes; Enfermería Pediátrica. 


\section{INTRODUCTION}

The process of hospitalization in a child's life is a change from every routine to which he/she is accustomed, since he/she is removed from family, friends and all his/her daily activities, causing his/her great suffering and stress. ${ }^{1}$ This situation can be enhanced when he/she needs to stay in single rooms, that is, in a precautionary environment, which deprives him/her of freedom and of being able to interact with others, especially with other children in the hospital ward.

Precaution is used when the child has multi-resistant microorganisms, as well as confirmation or suspicion of serious illness easily transmitted by direct contact or patient's fomites, such as respiratory, gastrointestinal and dermatological infections. ${ }^{2}$ In this sense, precaution becomes a physical and emotional barrier between the child and the external world.

The child who interacts with the precautionary situation can become sad and depressed, cry and ask to play outside, with others, because this experience increases their level of stress, as well as of their companion, who ends up being "isolated" with them. ${ }^{3}$

Researchers have been discussing emotional care as a right of the child, guiding the professionals' behavior to favor care that includes, besides the treatment of the disease, the promotion of their development and well-being, especially when they are hospitalized. ${ }^{4}$ To this end, it is necessary that the professionals involved in the care of the child help them to develop coping skills in the face of hospitalization, with emphasis on the use of different play activities. ${ }^{5}$

The play is a valuable resource for nursing, because through it the child exposes their feelings, helping them to understand the situations and procedures that are performed in it, favoring tranquility, safety and improving acceptance regarding treatment, as well as facilitating the relationship between the team and the child. ${ }^{6}$

Recognizing the relationship between the child and play is supported by studies that demonstrate the innumerable benefits that emerge from its use when the professional integrate it during their care, allowing the child to express their feelings, fears, anxieties, and concerns, establishing a relationship of trust with the caregiver, in addition to their benefiting from it by promoting their knowledge about the situations they experience..$^{7-9}$ In this sense, health professionals who are involved in child care cannot deprive them of this activity, regardless of the context in which they are inserted, including the precautionary situation.

Reflecting on the importance of play for the child who experiences the precautionary situation, some questions have arisen: How does a child hospitalized in precaution define the possibility of play? What interactions occur between him/her and who plays during the game? What emotions do you experience during the game?

Looking for answers to these questions and considering that when the literature was consulted in the main databases, no studies were identified that dealt with the playing for the hospitalized child in precaution, justifying the carrying out of this study that had as objective: to understand the meaning of play for the hospitalized child in precaution.

\section{METHOD}

A qualitative study using Symbolic Interactionism, which study focus is the nature of the interaction, considering that the human being is active and acts according to the meaning that he/she attributes to the situations with which he/she interacts. ${ }^{10}$ The data were submitted to Qualitative Content Analysis in its Conventional mode, which is appropriate when there is no theory or literary revision on the subject studied. ${ }^{11}$

Eight children, four girls and four boys, aged between 5 and 10 years old, were admitted to a public children's hospital in the city of São Paulo, which met the following criteria: being hospitalized in a private environment of precaution by contact, aerosol or droplet, regardless of the reason for their hospitalization; being in condition to play, interact with people, the environment and have stayed, at least, one day in precaution during interaction with the researcher.

The study scenario was chosen because it meets the criteria of the research, since it has a private room for children under the conditions of precautions, and it is the hospital norm that all children in this condition remain in a private room, not being allowed to attend the toy library. Although there is no entertainer to attend the child, loans can be made of the toys to them, which, when returned, are sanitized according to the institution's protocol. In addition, parents are allowed to bring their own toys to stay with him/her during his/her stay.

The number of participants was defined during the course of the field work when the "saturation point" was identified through the organization of the statements, that is, the existence of redundancy and repetition of ideas, patterns of behavior and worldviews, ${ }^{12}$ thus showing enough empirical material to respond to the study's objective.

Data were collected between April and September 2016, and the approaches used were: participant observation, during play activities developed by one of the researchers with the child, recorded in a field diary; and the semi-structured interview with the child, which was mediated by the Procedure of Story Drawing with Theme (PSD-T). ${ }^{13}$

The PSD-T is used when the subject has the ability to graphically and verbally represent some internal content and, in a symbolic way, relates that symbol to a particular dynamic. For its accomplishment, the examiner makes a question to the subject based on a certain theme, following the order during the elaboration: drawing (graphics expression), story, title and inquiry (questionings on the subject). ${ }^{13}$

The ludic activity took place on three consecutive days, in the same precautionary room or in another environment that the child desired when he was no longer in that condition. Each meeting lasted approximately one hour and a half, followed by a detailed description of the children's activities in the field diary. 
In order to guarantee the reliability of the speeches, the voice recorder of the researcher's cell phone was also used.

The first meeting aimed to establish a link between the child and the researcher. In this, they were approached in a playful way and, for that, was given a surprise kit, that is, a closed bag with a ribbon containing: modeling clay, crayons, blowing balls, A4 paper, black and colored pencil, memory game, ball, puzzle, domino, plastic doll, two toy cars, some household items and a toy cell phone. After this material was delivered to the child, they were invited to play, being free to propose the games. The choice of the toys was due to the characteristics of the development of the child and they remained with them after the ending of the play activities.

The second meeting took place on the same day, following the same dynamic. In the third meeting, after the play, the child was invited to perform the activity of the PSD-T and was asked to draw a child playing in the hospital room. The request was driven by the guiding question: "Are we going to draw a child who is playing in the hospital room?" At that moment, the child was offered the material recommended by the PSD-T technique: A4 paper, colored pencils, and graphite pencil. ${ }^{13}$

According to the PSD-T, after the guiding question, the child had the necessary time to make the drawing and to finish it, the researcher asked her to tell a story about it or to talk about what she draw, if she wanted to. In addition, questions were raised regarding the same and others related to the child's condition in relation to playing in the precautionary situation, since this method was used as a mediator for the semi-structured interview.

In the analysis of data, the steps guided by the Qualitative Analysis of Conventional Content were covered: codification, categorization, and description of the thematic categories representative of the phenomenon studied. ${ }^{11}$

All ethical aspects involving research with human beings were respected in accordance with Resolution 466/2012 of the National Health Council and approved by the Research Ethics Committee of the Federal University of São Paulo under Opinion No. 1,237,939/2015, including the signing of the Term of Free and Informed Consent by those responsible and the Term of Assent by the child, before the first meeting, after the same were oriented about the study. The anonymity and secrecy of the children were maintained and, for that, they chose fictitious names to represent them: Ana, Ash, Snow White, Gustavo, Pedro, Princess Aurora, Superman and Ytawane.

\section{RESULTS}

From the analysis of the data, the emerged concepts are described in the thematic categories, exemplified by empirical data identified by the initials: "R" for researcher; " $C$ " for child; "M" for the mother of the child; "S" for the child's siblings; D1, D2 and D3 for the first, second and third day of play interaction, PSD-T for Procedure of Story Drawing with Theme and by the pseudonym of children.

\section{Opening for playful interaction}

This category describes how the child was at the arrival of the researcher in the three days of play activity and how the acceptance occurred to participate in the game, revealing that he/she readily accepted the invitation to play, even on the first day, when he/she did not know the researcher or presented some physical difficulty. There was also a positive evolution of their interactions, showing how much the children were more relaxed and relaxed.

Child sitting on her bed without doing any activity and with her mother. After the researcher reads the Term of Assent, the child readily accepts the invitation to play (Ana, D1).

Child readily accepts the invitation to play, even when feeling strong body aches, asking the mother's help to sit down and sign the Term of Assent (Ytawane, D1).

Child lying down watching television, presenting himself less tachypneic and wearing 02 mask. At the entrance of the researcher, nods positively, accepting his entrance. $R$ : How did you spend the day? C: All right! (smiling). S: He's much better today (Superman, D2).

Child lying down, relaxed, sucking pacifier and watching TV (Princess Aurora, D3).

In addition, it reveals the need for the child to have their time respected after being subjected to some event that has caused fear and stress, such as a venipuncture. In this case, the acceptance of the child to play was preceded by intense crying, frightened facial features and accepting the suggestion of the return of the researcher after feeling calmer.

Child undergoing venipuncture and crying long before the researcher entered the room. Nurse: She's crying a lot and she's angry! After minutes, the child remains crying and with the hand covering the eyes, avoiding eye contact with the researcher when she enters the room. R: No problem you crying! Do you want me to stay in the room? $C$ : Shaking her head. R: Can I come back after you're calmer? C: Nods positively. After a few more minutes, the researcher beckons the child to enter. $C$ : Nods the head positively, sitting quickly as soon as the researcher enters the room to start the play activity (Snow White, D3).

\section{Exploring the material of the surprise kit}

Upon receiving the surprise kit, the first manifestation of the child was to explore toys in a variety of ways, experimenting with and discovering the different possibilities they can offer. Some manipulate a same toy more than once, others name it by removing it from the bag, and there are still those that separate it by gender, according to the meaning they attribute to them, as being appropriate or not to the games of boys or girls. 
Child unties the surprise kit and begins to remove the toys one by one while manipulating and grouping them (Snow White, D1)

Child removes the doll from the surprise kit, looks at the mother and smiling: doll! (Ytawane, D1).

The child asks the researcher to open the surprise kit and remove the toys [...]. He takes the cell phone, opens it and presses a few keys, placing it on his ear. Then he puts it on the bed [...]. After the researcher pulls the doll from the surprise bag, he says: I do not play with dolls! (Superman, D1).

Child removes the doll, looks at his mother and says: I'll give it to $L$ ! Removes the pots, puts them with the doll and repeats to the mother: I will also give the pots to L. M:You can play with the toys, even if they are for girls. C: I'll give it to L! R: Is L your sister? C: My neighbor! (Pedro, D1).

\section{Becoming the protagonist during the play}

This category reveals that, when playing, the child places himself/herself in the situation of the protagonist, valuing himself/ herself, positioning himself/herself and having a voice. Thus, he/she is included in the drawing with positive words regarding his/her self-image and builds his/her own piece of dominoes.

The child asks the researcher to take the pencil so he/she can draw [...]. When the drawing is finished, asks the researcher to take the box of colored pencils. He paints the whole drawing and writes his name. R: What did you draw? C: Myself! R: Where were you? C: Here! (Referring to the hospital). R: How are you feeling? C: Feeling well! Take the drawing again and write 'I'm cute'. R: Who are you talking to? C: Myself, he says smiling! (Superman, D1).

The child picks up two little pieces of dough, hands one to the researcher, keeping the other, starting to press it on the bed [...]. He kneads hard on the bed, takes a piece of dominoes, presses it on the clay leaving its shape. Turns the clay on the other side, takes a pencil and writes their name. R: What did you do? C: My own domino! (Gustavo, D1).

During the development of the play activity, the child also manifests actions that show his/her opportunity to dominate the situation, such as: ordering the researcher, in an authoritarian way, to take the ball and not allowing him/her to see the pieces he/she chose during the memory game.

The child picks up the ball, looks sarcastically at the researcher and then throws it off the bed and says in an authoritative tone and pointing to the ball: pick it up! (Snow White, D1).
C: Let's play another game! R: Which one? C: I forgot the name! R: The one we played yesterday? The memory game? C: That's it! The child turns the pieces of the game, shuffles them, putting them in alignment. Then, when realizing that the researcher matched the pair, he started to play faster and didn't allow to see the chosen piece, getting excited when he got it right (Superman, D3).

\section{Expressing their feelings and desires through play}

This category reveals that playing gives the child a moment of happiness, in which he/she laughs, enjoying the joke and amuses himself/herself as he/she engages in a playful activity, as in simulating the commemoration of a goal during a soccer game.

Child invites the researcher to play table football. Teaches the researcher how the game is and starts playing. As he approaches the goal post, he begins to narrate the game and when he scores, he is happy, vibrates and hits the button on the table, pretending to be celebrating (Superman, D2).

When interacting with the researcher during play activity, be it dramatizing or talking with her, the child will reveal, explicitly or symbolically, their feelings and desires. In this sense, the child expresses, for example, the feeling of being imprisoned and her desire for freedom by playing with two balloons, attributing to them the meaning of an animal that can fly or, during a play of clay, saying that the person which was modeled was on the beach and made a friend.

The child picks up the filled balloons with the hand, swings them from one side to the other and give them to the researcher to tie them. R: Do you want to play of what? C: Play of flying! M: Is that a butterfly or a bird? C: A little bird! R: What's it name? C: Quack Quack Quack! M: This is not a bird, but a duck! C: It's a duck! R: And what was it doing? C: Flying! R: Where was it flying to? $C$ : To far away! (Princess Aurora, D1).

R: Let's play what? C: Let me think ... Clay! R: What are you going to do? C: A person! R: And what can I do? C: A dog! [...] R: Who is this person that you did? C:I do not know! R: How was he feeling? C: Well! R: Where was he? $C:$ At the beach! R: What was he doing on the beach? $C$ : Lying on the sand! R: And what was he thinking while lying on the sand? C: On how good life is! And takes another clay and say: Now I'm going to make a snake! [...] R: What is the name of this snake? C: Can it be male or female? R: It can be whatever you want! C: It's Chico! R: How is Chico feeling? C: Good! R: Where is Chico? $C$ : On the beach! R: What was it doing on the beach? $C$ : Seeing the sea! R: Who was Chico with? C:Alone! R: Did Chico know that person who was on the beach? C: No, but they talked and became friends! (Superman, D2). 
Feeding was very present during the game, demonstrating the child's desire to eat foods that are not offered to him/her at the hospital. It also allowed him/her to express his/hers desire to have a home, as he/she claims to be his/her mother's dream.

Child playing that the balloon was a duck and that this one was flying. R: And what did he (the duck) do away? C: It was eating! R: Eating what? C: Egg! R: And you like eggs? ... What's your favorite food? C: Sausage! R: And what else do you like? C: Rice with sausage! (Princess Aurora, D1).

Child finishes the drawing and explains to the researcher what she had drawn: I made a smaller house to play with, a soccer field for my brother and an internet antenna! My mother's dream is to have a house like that! (Ytawane, D1).

\section{Relieving stress and organizing oneself through play}

In this category, other benefits are revealed that engaging in a playful environment conducive to the child. By playing, there is relief from the stress and tension experienced by them, when they interact with atypical situations that can generate stress or require them to remain calm, such as waiting for the results of exams.

R: And how did he/she (child from the drawing) feel waiting for the result of this examination? C: Nervous! $R$ : And what did she do to calm down? C: She was joking! $Q$ : And what most calmed her down? C: The games! (Ana, PSD-T, D3).

In addition to relieving stress, the child has the opportunity to organize himself/herself while engaging in a playful activity. This organization occurs from the beginning of the game, when the child decides which toy will remain and which will give to the researcher, as when delivering the clay of the same color of the toy pot.

C: Let's play clay! Distribute the purple clay to the researcher, keep the green and say: Let's use the pots! Then she hands the purple purse to the researcher, keeping the green and says: Look, it's just like your color and mine! R: I'll make a cake, and you? C: Worm soup! Then, carefully cut small pieces of clay, wrap them up in the small clump. [...] The researcher delivers the cake she made to the child, who places it in an organized fashion next to her. C: I'll make another cake! It's ready! Put the cake next to the last one saying: Today, we're only making candy! Make the last cake; put it next to the others, leaving all of them perfectly aligned (Snow White, D2).

\section{Determined to continue the playing despite the difficulties and limitations}

Although the child has some limitation or difficulty that could impede or hinder the play, he/she tries to keep playing, asking the researcher for the pencils of the color he/she needs when he/she cannot catch them alone or keeping the punctured member unmoved during the game with the blowing balloon.

The child responds to the researcher who wants to draw, asking the mother for help to sit comfortably. Asks the researcher to take the pencil [...]. When he finishes drawing, he asks the researcher to take the box of colored pencils to paint the drawing and asks for the pencils of the color he wants as he paints his drawing (Superman, D1).

A child plays of blowing ball with the researcher using one hand, while holding still the other, which is with the peripheral venous device, being careful not to pull it (Ana, D2).

\section{Defining the hospital as a place of suffering, procedures, and restrictions}

In addition to all the benefits described in the other categories, the play facilitated the possibility of the child revealing their perception about the hospital and the nursing care, as this category shows. He/She defines it as a place where he/she is alone, sad, imprisoned, with no one to play, living with the suffering imposed by the disease and the restrictions of the hospital environment, associating the health professional with the one who performs only technical procedures, which is why they feel threatened with her presence.

R: How was this boy feeling before when he came to the hospital? C: Before? On the first day? R:Yes! C: Half worried! R: Worried about what? C: Like ... if he vomited, a lot of stuff I cannot explain right. R: How did he feel? C: Sad, very sad! (Ash, PSD-T, D3).

R: That child you drew, could he/she play? Could he/ she leave? C: Not yet! R: Why? C: Because he/she was in isolation. R: Why was he/she in isolation? C: Because he/she had to do an exam first to see if he/she had no bacteria [...] R: How did you feel about living here in the room these days you could not get out? C: Very boring, I felt a little stuck! (Ana, PSD-T, D3).

$R$ : And do they (nurses) play with you? C: Yes, but not with me, only with him (drawing boy). R: Do they play about what with him? C: Of doctor! R: What's the doctor's game like? C: Put on a hospital outfit, take the glove and put it on the nose, put it here, pointing it to the ear, and here and the thing gets in the nose, points to the nose (Gustavo, PSD-T, D3). 
Child painting when a nursing technician enters his room and puts the tray on the table. Then she interrupts the play, looks at her suspiciously and frightened. M says: He already thinks it's a needle! (Peter, D1).

\section{From lonely play to the importance of shared play}

When interacting with an adult who is willing to play and who values this activity in the room where he/she is deprived of living with other children, the child is no longer lonely in play and in the environment.

$R$ : What was the child doing in the room when the nurse arrived? Playing. Q: Playing of what? C: Of doll! Q: She was playing with who? C: Alone! (Snow White, PSD-T, D3).

Child telling about his/her drawing: first the child had nothing to do and won like this, as if they were the title of the story. And the child was alone with the mother, with nothing to do, then came a person, brought a gift to the child and played with him/her. And the child becomes very happy [...]. The child plays, the child gets sick, the child is full of things, but there are times that he/she is happy, there are times that he/she becomes sad. First, he/she was sad, then he/she was happy because that person helped him/her to be happy. R: How was this child feeling before that person came to play with him/her? C: Very lonely, with nothing to do, with nothing to do, had nothing. If I had a little something, but still, it was still little. (Ytawane-PSD-T, D3)

In addition, the data revealed the potential of shared play to promote and strengthen the bond between the child and the nurse.

Mother tells the researcher: He (the child) was worried that he might be discharged today and said: "Mother, if I am discharged today, " $J$ " (the researcher) will come here and I will not be able to play with her! (Gustavo, D3).

R: Did you enjoy our days together? C: You are very cool, you'll stay in my heart! (Ytawane, D3).

C:Do you keep visiting the other children of the research? R:Whenever I am in the hospital and if I have any children from my research I visit. Child smiles relieved (Ash, D3).

\section{DISCUSSION}

According to the interactionist perspective, the child is an active being, a social actor, who participates and interacts with different people and situations, assigning meanings to the processes experienced in the social world, acting in each situation, according to the meaning attributed to him/her.
Thus, when he/she is in precaution, the child establishes, through play, interactions with the available objects, seeking other forms of amusement beyond the games shared with his/her peers, which gives him/her moments of joy and distraction, as occurred with the children in this study.

In addition to the joy and distraction, when they played, the children became more calmed and relaxed, corroborating a study that aimed to apprehend the perception of the companions of children about the storytelling during the hospitalization, with which they became more animated, besides this activity having helped to calm them down. ${ }^{14}$

To important theorists of play, such as Piaget ${ }^{15}$ and Vygotsky, ${ }^{16}$ the children's affinity for play activities is undeniable since they are part of their nature when dealing with the world. Thus, they accept to participate in the game not only because they like and it delights them, but because it is the play a childhood need, taking precedence over the others, as demonstrated by Ytawane, who, even in pain, accepted the invitation promptly to play.

This fact occurred even when this invitation was preceded by a stressful event, showing how much the children needs to have their time respected so that they can recover and then be able to participate in the game, as happened with Snow White who, after being punctured, had first to calm down and then played with the researcher. We believe that nurses are aware of this need when interacting with the child in the daily care.

After accepting the invitation to play and receiving the material offered by the researcher, the children presented different manifestations, interacting with the toys cheerfully, naming them, getting to know their functions and separating them by gender, findings that resemble the results of a study that sough $t$ to analyze how the session of Therapeutic Play happened, identifying that, in the stage of exploration, the child acts in three distinct ways: observing, looking attentively and meticulously at the toys and the environment; handling the objects used to play; verbalizing and asking questions about them. ${ }^{17}$

Regarding the separation of toys, according to gender, the literature points out as quite significant in the playfulness of children of both sexes, but more evident among boys. ${ }^{18}$ However, a study with children in sickness situation found little segregated episodes, suggesting singularity aspects of this condition. ${ }^{19}$

Another relevant finding of this study was that the interaction between child-toy-person that plays allowed the construction of a significant relationship between these and also the child with her internal and external environment, between the real and the imaginary, between the body and the world, allowing her to come out of a situation of passivity, to have voice, to dominate the situation and being able to test and dominate the other.

In this sense, listening to them, gives the opportunity for the construction of relationships, besides being an important strategy within the context of hospitalization, ratifying that the child's protagonism is necessary for the decision-making related to her, in order to transpose her invisibility in the process of illness and hospitalization, an aspect that has been emphasized in the literature. ${ }^{20,21}$ 
For this, it is fundamental to value the children's playful expression in the different scenarios where the kids are inserted, because through play, there is the construction of themselves and their role in the world, that is, of their personality as a subject worthy of expressing themself. ${ }^{22}$

In this research, the play also allowed the child to express, symbolically or through conversation with the researcher, the desire to free themselves from the confinement due to being hospitalized and in precaution. Playing, the children were able to share current wishes and future dreams, talk about their favorite foods, express their desire to move from there to another place that refers to freedom and to the continuity of life.

A study that aimed to understanding the meaning of hospitalization for children and adolescents with chronic diseases revealed that when the child was hospitalized, he/she reported losing his/her freedom; but when he/she plays he/she has the opportunity to re-signify those experiences that are unpleasant for him/her, transforming this situation into a pleasant experience, as manifested by a child of that study, who drew the sky with birds flying and the sun illuminated. ${ }^{23}$

Playing, for the child, also enables stimulation of their potentialities and creativity, and also promotes interaction and communication with others and with the world. However, when inserted within the hospital context, this playing ends up also exerting a therapeutic function, ${ }^{24}$ providing an improvement in physical and emotional well-being.

International literature has emphasized the benefits of playing for stress and fear relief in the different situations in which it was used. At a university in Canada, was created the educational program called the Teddy Bear Clinic Tour, which is set up as a walk through the hospital for approximately 45 minutes during which the children become familiar with hospital objects and possible spaces they may need to use one day, such as the radiology exam room. ${ }^{25}$

The results of this program showed that there was the reduction of fear and expectation of pain in the face of invasive procedures. In addition, the children sought coping strategies to overcome such situations, such as verbalizing that the needle would not cause him/her so much pain or telling a funny story. ${ }^{25}$

Other studies have shown that, regardless of how the play is used, when used in care practice, there is a reduction in the stressors that result from therapeutic care or from the own hospitalization. ${ }^{26,27}$ When playing, the children begins creating strategies to solve a problem they are facing and trying to (re) organize themselves within an atypical situation for them, such as illness and hospitalization, ${ }^{6,25}$ as it was revealed in this study in Ana's speech, when she told that she was playing to calm herself while she waited for the results of the examinations.

It is worth mentioning that, during the period of hospitalization, the child, in most cases, does not experience the same games that he/she would play at home, at school or on the street. This is due to the limitation of the physical space, their physical condition, the treatment and the types of care imposed on them, in addition to being connected to devices, such as an infusion pump or being restricted to the bed, making it difficult to play games that require vigorous motor coordination. ${ }^{28}$ In this research, when interacting with some of these difficulties, the children developed strategies to continue playing.

Although children may encounter different situations that prevent them from playing, the child tends to become involved in activities that do not necessarily consist of his or her favorite ones, but instead include them in his or her routine inside the hospital, ${ }^{28}$ demonstrating that the play becomes prioritized in face of some type of problem which is being confronted and that he/she maintains the interest in the playful activity.

The hospital, even though it is a place that is usually seen as a context of care to disease, also allows the child to socialize and establish interactions, and the power to act as a child is done through play. ${ }^{22}$ By playing, it subverts power relations from the health professionals, breaking the logic of submission to adults, thus becoming free of any bonds. ${ }^{29}$

By playing, children re-signify the hospital as a place that allows health maintenance, and therefore an appropriate environment for performing playful activities, ${ }^{30}$ since for them to have health means to play, to have energy and to do the things they want. ${ }^{31}$ When they play, they feel free to express themselves, broadening the social imaginary about the hospital, as a place that can bring them pleasure..$^{30}$

In addition, in interacting with the fact that he/she is ill, the child feels unwell, in pain, sad and does not want to do things, ${ }^{22}$ corroborating the data of this research, in which he/she says he/ she feels very sad about being sick. In this sense, the sick and hospitalized child needs to adapt to this new situation, developing coping strategies to deal with all this experience, which is atypical for his/her age. ${ }^{1,6,25}$ Among them, in this study recreational play was used, promoted by the nurse, with children hospitalized and in precaution.

Playing, there is a new construction of relational patterns within the hospital since the child starts to take a new look at who cares for him/her, no longer perceiving the team as the one who only sees him/her as a clinical picture, as someone who performs only technical procedures. ${ }^{20}$ Through the play, it starts to re-signify the place and the health professionals, giving them a new meaning, and defining them as actors who care about being a child, in agreement with Vygotsky, for whom the playing allows not only that the child understand as to re-signify a situation that is being experiencing. ${ }^{16}$

According to Symbolic Interactionism, the interaction is directed by symbols that guide the interpretation of a lived situation, ${ }^{10}$ so that while playing, the child attributes meanings to objects and actions and recalls their experiences. Thus, their verbal and non-verbal expressions in play show how they interact with themselves, with the environment and with the people around them, and how they define their illness and their experiences in the precautionary room. 
In addition, the children participating in this research demonstrated the strength of the bond established with the researcher from the play, even worrying about the possibility of no longer finding the researcher in the hospital.

We agree that in promoting play activities, the nurse not only assists the children to ensure their place in the world and minimize the negative repercussions of the whole hospitalization process, but also in establishing relationships and strengthening the bonds between professional and them, favoring a positive exchange between all those involved..$^{6,20}$

In addition, it should be remembered that play is a right guarantee by the Statute of the Child and Adolescent in Law $n^{\circ} 8.060$ of July $13^{\text {th }}, 1990$, in its articles 15 and 16 which deals with the right of freedom, respect, and dignity as people in the process of development, including the right to play and have fun. ${ }^{32}$ Thus, regardless of the context of health in which the child is inserted, they should not be deprived of it.

\section{FINAL CONSIDERATIONS}

The results of this study will help nursing professionals to look at the child in a holistic way, offering them subsidies to meet their need to play while they are in the private precautionary room while hospitalized.

In order to guarantee integral assistance to this child, nurses must use their creativity, seeking strategies that allow them to play in this environment full of restrictions, aiming to reduce the stressors determined by this condition, favoring that the care becomes less imposing and more humanistic, in accordance with the purposes of Nursing.

In this sense, nurses should engage in the promotion of play activity and incorporate it into their daily care practice, aiming at establishing and narrowing the bond, favoring care delivery, demystifying the image of the nurse as the professional who performs only procedures that cause pain to the children, propitiating the expression of the child, making hospitalization a less traumatic event, making it possible that, through playing, they continue to be a child and can be freed from the confinement of being hospitalized and in precaution.

In addition, it is worth noting that the non-use of play by health professionals in practice is due to the lack of scientific knowledge regarding its importance for the child's growth and development, as well as a right guaranteed by law regardless of the context is inserted.

Since the literature presents gaps related to playing activity for children who experience the precautionary environment and considering that this study has limited itself to studying the use of recreational play, we recommend that other researches be carried out in order to understand how the children interact with the environment of the precaution, what means for them to experience this process, how the parents perceive and engage in playful activities with the children that are in precaution, as well as to verify the effect of the different types of play, both in the behavior and in the process of their recovery.

\section{ACKNOWLEDGEMENTS}

To the Conselho Nacional de Ciência e Tecnologia (CNPq) for the grant of masters scholarship;

To the Director of Nursing, Nurse Marta Marina Teixeira da Silva and all the team of the Darcy Vargas Children's Hospital for the support throughout the accomplishment of this study.

\section{REFERENCES}

1. Siegel J, lida H, Rachlin K, Yount G. Expressive Arts Therapy with Hospitalized Children: A Pilot Study of Co-Creating Healing Sock Creatures. J Pediatr Nurs [Internet]. 2016 Jan/Feb; [cited 2017 Oct 4]; 31(1):92-8. Available from: http://www.pediatricnursing.org/ article/S0882-5963\%2815\%2900273-0/abstract. DOI: 10.1016/j. pedn.2015.08.006

2. Siegel JD, Rhinehart E, Jackson M, Chiarello L; the Healthcare Infection Control Practices Advisory Committee. Guideline for Isolation Precautions: Preventing Transmission of Infectious Agents in Healthcare Settings. [Internet]. 2007; [cited 2017 Oct 4]. Available from: https:// www.cdc.gov/infectioncontrol/pdf/guidelines/isolation-guidelines.pdf

3. Marques FRB, Schwartz E, Marcon SS. Experiência de mães em ter um filho diagnosticado e hospitalizado pelo vírus Influenza A (H1N1). Rev Bras Enferm [Internet]. 2014; [cited 2017 Oct 4]; 67(2):220-6. Available from: http://www.redalyc.org/articulo.oa?id=267030687008. DOI: 10.5935/0034-7167.20140029

4. Lamber V, Coad J, Hicks P, Glacken M. Young children's perpectives of ideal physical design features for hospital-built environments. J Child Health Care [Internet]. 2014 Mar; [cited 2018 May 7]. 18(1):57-71. Available from: https://www.ncbi.nlm.nih.gov/pubmed/?term=Young+ children\%C2\%B4s+perpectives+of+ideal+physical+design+features +for+hospital-built+environments. DOI: $10.1177 / 1367493512473852$

5. American Academy of Pediatrics. Child life Servicers. Committee on Hospital Care and Child Life Council. Pediatrics [Internet]. 2014; [cited 2017 Oct 6]; 133(5):1471-78. Available from: http://pediatrics. aappublications.org/content/pediatrics/133/5/e1471.full.pdf. DOI: 10.1542/peds.2014-0556

6. Depianti JRB, Silva LF, Carvalho AS, Monteiro ACMM. Nursing perceptions of the benefits of ludicity on care practices for children with cancer: a descriptive study. Online Braz J Nurs [Internet]. 2014; [cited 2017 Oct 6]; 13(2):158-65. Available from: http://www.objnursing.uff. br/index.php/nursing/article/view/4314/pdf_119

7. Chen HJ, Hsu YC, Hu YF, Chung YY. Therapeutic play Promoting Children Health Management Preschool Children Aerosol Therapy Completion Rates. Int J Res Manag Bus Stud [Internet]. 2014 Mar; [cited 2017 Oct 7]; 1(1):88-92. Available from: http://ijrmbs.com/vol1 issue1/2/ yuchin.pdf

8. Manav G, Ocackci AF. Play model for "evaluation of self-concept of children with cancer". Iran J Nurs Midwifery Res [Internet]. 2016 Mar/ Apr; [cited 2018 May 7]; 21(2):124-30. Available from: https://www. ncbi.nlm.nih.gov/pubmed/?term=Manav+G\%2C+Ocackci+AF.+Play +model+for+evaluation+of+self-concept+of+children+with+cancer. +Iran+J+Nurs+Midwifery+Res.+2016\%3B+21(2)\%3A124-130. DOI: 10.4103/1735-9066.178227

9. Koukourikos K, Tzeha L, Pantelidou P, Tsaloglidou A. The importance of play during hospitalization of children. Mater Socimed [Internet]. 2015 Dec; [cited 2018 May 7]; 27(6):438-41. Available from: https:// www.ncbi.nlm.nih.gov/pubmed/?term=The+importance+of+play+dur ing+hospitalization+of+children.+Professional+Paper. DOI: 10.5455/ msm.2015.27.438-441

10. Charon JM. Symbolic interacionism: an introduction, an interpretation, an integration. 10 ${ }^{\mathrm{a}}$ ed. Englewood Cliffs: Prentice Hall; 2010.

11. Hsieh HF, Shannon SE. Three approaches to qualitative content analysis. Qual Health Res [Internet]. 2005 Nov; [cited 2018 May 7]; 15(9):1277-88. Available from: https://www.ncbi.nlm.nih.gov/pubme $\mathrm{d} /$ ?term =Hsieh+HF\%2C+Shannon+SE.+Three+approaches+to+qua litative+content+analysis 
12. Fontanella BJB, Ricas J, Turato ER. Amostragem por saturação em pesquisas qualitativas em saúde: contribuições teóricas. Cad Saúde Pública [Internet]. 2008 Jan; [cited 2018 May 7]; 24(1):1727. Available from: http://www.scielo.br/scielo. php?pid=S0102311X2008000100003\&script=sci_arttext\&tlng=pt

13. Trinca W. Procedimento de Desenhos-Estórias: Formas derivadas, desenvolvimentos e expansões. São Paulo: Vetor; 2013.

14. Nicolino TNA, Barbieri MC, Tacla MTGM, Ferrari RAP. Contação de história na unidade pediátrica: percepção de acompanhantes de crianças hospitalizadas. Rev Enferm UFSM [Internet]. 2015 Jan/Mar [cited 2017 Oct 06]; 5(1):32-9. Available from: https://periodicos.ufsm. br/index.php/reufsm/article/viewFile/13204/pdf. DOI: http://dx.doi. org/10.5902/2179769213204

15. Piaget J. A Formação do Símbolo na Criança: Imitação, Jogo e Sonho, Imagem e Representação. Rio de Janeiro: Zahar Editores; 1978.

16. Vygotsky LS. A formação social da mente. $7^{\underline{a}}$ ed. São Paulo: Martins Fontes; 2007

17. Santos VLA. A sessão de Brinquedo Terapêutico: contribuições para sua compreensão e utilização pelo enfermeiro [tese]. São Paulo (SP): Universidade Federal de São Paulo; 2012.

18. Morais MLS, Otta E. Entre a serra e o mar. In: Carvalho AMA, Magalhães CMC, Pontes ARP, Bichara ID, eds. Brincadeira e cultura: viajando pelo Brasil que brinca. São Paulo: Casa do Psicólogo; 2003. p.127-56.

19. Gomes ST. Criança-contexto: caracterização das atividades lúdicas em uma casa de apoio [dissertação]. Salvador (BA): Universidade Federal da Bahia; 2009.

20. Santos PM, Silva LF, Depianti JRB, Cursino EG, Ribeiro CA. Nursing care through the perception of hospitalized children. Rev Bras Enferm [Internet]. $2016 \mathrm{Jul} /$ Aug; [cited 2017 Oct 6]; 69(4):603-9. Available from: http://www.scielo.br/pdf/reben/v69n4/en_00347167-reben-69-04-0646.pdf. DOI: http://dx.doi.org/10.1590/00347167.2016690405

21. Ribeiro CA, Borba RIH, Maia EBS. O preparo da criança e da família para procedimentos terapêuticos. In: Gaiva MAM, Ribeiro CA, Rodrigues EC, orgs. PROENF: Programa de Atualização em Enfermagem: Saúde da Criança e do Adolescente: Ciclo 8. Porto Alegre: Artmed/Panamericana; 2013. p. 9-49.

22. Moreira MCN, Gomes R, Sá MRC. Doenças crônicas em crianças e adolescentes: uma revisão bibliográfica. Ciênc Saúde Coletiva [Internet] 2014; [cited 2017 Oct 7]; 19(7):2083-94. Available from: http://www. scielo.br/scielo.php?pid=S1413-81232014000702083\&script=sci abstract\&tIng=pt. DOI: http://dx.doi.org/10.1590/141381232014197.20122013
23. Luz JH, Martini JG. Compreendendo o significado de estar hospitalizado no cotidiano de crianças e adolescentes com doenças crônicas. Rev Bras Enferm [Internet]. 2012; [cited 2017 Oct 7]; 65(6):916-21. Available from: http://www.redalyc.org/pdf/2670/267025361005.pdf. DOI: http:// dx.doi.org/10.1590/S0034-71672012000600005

24. Baldan JM, Santos CP, Matos APK, Wernet M. Adoption of play/toys in the assistance practice to hospitalized children: nurses' trajectory. Ciênc Cuid Saúde [Internet]. 2014 Apr/Jun; [cited 2017 Oct 7]; 13(2):228-35. Available from: http://eduem.uem.br/ojs/index.php/CiencCuidSaude/ article/view/15500/pdf_197.DOI:10.4025/cienccuidsaude.v13i2.15500

25. Dalley JS, McMurtry CM. Teddy and I Get a Check-Up: A Pilot Educational Intervention Teaching Children Coping Strategies for Managing Procedure-Related Pain and Fear. Pain Res Manag [Internet] 2016; [cited 2017 Oct 7]; 2016:4383967. Available from: http://dx.doi. org/10.1155/2016/4383967

26. Anes L, Obis M. Hospital clowning as play stimulus in healthcare. Children [Internet]. 2014; [cited 2017 Oct 7]; 1(3):374-89. Available from: http://www.mdpi.com/2227-9067/1/3/374/html. DOI: 10.3390/ children 1030374

27. Cunha GL, Silva LF. Lúdico como recurso para o cuidado de enfermagem pediátrica na punção venosa. Rev Rene [Internet]. 2012; [cited 2017 Oct 7]; 13(5):1056-65. Available from: http://www.revistarene.ufc.br/revista/ index.php/revista/article/view/49/pdf

28. Hostert PCCP, Enumo SRF, Loss ABM. Brincar e problemas de comportamento de crianças com câncer de classes hospitalares. Psicol Teor Prat [Internet]. 2014 Jan/Apr; [cited 2017 Oct 7]; 16(1):127-40. Available from: http://editorarevistas.mackenzie.br/index.php/ptp/article/ view/5366

29. Lopes BA, Oliveira Junior CR, Oliveira VB. O brincar como instrumento de resgate do cotidiano da criança hospitalizada. Bol Acad Paul Psicol [Internet]. 2015; [cited 2017 Oct 8]; 35(88):93-108. Available from: http:// www.redalyc. org/articulo.oa? id $=94640400007$

30. Silva LF, Cabral IE. Rescuing the pleasure of playing of child with cancer in a hospital setting. Rev Bras Enferm [Internet]. 2015; [cited 2017 Oct 8]; 68(3):337-42. Available from: http://www.scielo.br/pdf/ reben/v68n3/en_0034-7167-reben-68-03-0391.pdf. DOI: http://dx.doi. org/10.1590/0034-7167.2015680303

31. Moreira PL, Dupas G. Significado de saúde e de doença na percepção da criança. Rev LatinoAm Enferm [Internet]. 2003 Nov/Dec; [cited 2017 Apr 4]; 11(6):757-62. Available from: http://www.revistas.usp. br/rlae/article/view/1828/1879. DOI: http://dx.doi.org/10.1590/S010411692003000600009

32. Lei n. 8.069 de 13 de julho de 1990 (BR). Dispõe sobre o Estatuto da Criança e do Adolescente e dá outras providências. Brasília (DF): Diário Oficial da República Federativa do Brasil; 1990. 